\title{
Yezidis in ancient India, or Indians in ancient Mesopotamia?: Re-imagining Ancient Yezidi Origins
}

\author{
Mija Sanders ${ }^{1}$ \\ University of Arizona, Tucson, USA
}

\begin{abstract}
Members and leaders of the Kurdish speaking Yezidi diaspora in Phoenix, Arizona - and transnationally — are in dialogue with members of the Indian diaspora about their common historical connections. "Are Yezidis from ancient India, or are Indians from ancient Mesopotamia?" Both of these claims and hypotheses situate Yezidis on the outside of a historical Muslim world, and have material effects. They add validity to non-Muslim traditions, by imagining a historical cultural root structure between India and Mesopotamia. They also help both Hindu nationalists and Yezidis to displace historical Muslim culture and dominance to somewhere else while reinforcing tropes of Islam synonymous with the "war on terror." By de-historicising Islam and its presence in the Middle East and in India, Hindu and Yezidi community leaders co-imagine a pan-polytheism with roots in ancient Persian (Kurdish) Yezidi culture and language. The symbols that can be recognized today that span both traditions - the peacock, the peacock statue (sanjak), and the use of fire in places of worship - give testament to that imagined past. The contradictions of that historical narrative point to the limits of this historical work in the two communities, and find limits in modern identity articulations of Yezidi identity and Hindu identity alike. Material effects of the historical narrative include Indian imagery on the wall of Lalish, online circulating images and articles equating Yezidis to Hindus, and common activism, fundraising, and humanitarianism between Yezidi and Hindu communities in Phoenix, India, and in the Middle East.
\end{abstract}

Keywords: Yezidis, Kurdish diasporas, ethnography, and Hindu.

\section{Introduction}

In images of peacocks from Hinduism, some Yezidi $^{2}$ families in Arizona have found a familiarity, or even sense of recognition of their own tradition. On one occasion I accompanied a Yezidi family to a local Krishna temple on Janashtami, the birthday of Lord Krishna. The family was extremely happy to see the aarti fire ceremony, and the peacock lamps at the head of the altar, which exactly resembled their own Peacock lamp sanjaks. They kissed the peacock lamps and offered reverence. When the aarti tray of candles was passed around, they took the blessings of the fire. It was a space in which they felt comfortable to recognize and compare their own forms of worship from Lalish. They visited the gift shop and took home the inventory of peacock feathers. It was a joyous occasion for them, especially for the children. Following the visit, the father asked me to research the historical connections between Yezidis and Hindus. I responded that the common connections of peacock deity worship, of fire ceremonies, a caste system $^{3}$ and reincarnation were important if Yezidis felt a sense of mutual recognition, affect, or belonging. Attending Janashtami became an annual event for the family.

Other Yezidis in the diaspora have been visiting Hindu temples in recent years. In October, 2014 the Baba Sheikh, the religious head of Yezidis worldwide, visited a Murugan Temple ${ }^{4}$ in Washington, D.C. (Harrigan, 2015) A Yezidi scholar (van Bruinessen, 2018) commented on the uncanny interactions of the Baba Sheikh when he was asked to pray at the temple. The visit was filmed (Harrigan, 2014), and has been used as justification for the common origin

\footnotetext{
1 Correspondence; $\mathrm{PhD}$ student in the School of Middle Eastern \& North African Studies at the University of Arizona. E-mail; mijas@email.arizona.edu

${ }^{2}$ In this article I use the term "Yezidi" because it is the spelling which is most common in recent scholarly literature on the community. In Kurdish the word is spelled "Ezidi." I have used the word Yezidi for continuity with the literature, but in cases where the community has referred to themselves, they have used the word "Ezidi."

${ }^{3}$ Yezidis adhere to a socially religious caste system which differentiates on the broadest level between Murids (common caste, most Yezidis) Pirs (caste with priestly and religious responsibilities) and Sheikhs (highest ranking caste which is the only caste eligible to represent Yezidis politically). The castes are not demarcated by skin color or language, such as in India. They are strictly adhered to in terms of historical and contemporary marriage practices, and the upper castes have smaller groupings within which only they can marry.

${ }^{4}$ Murugan is a name of a son of Lord Shiva, who is represented in the form of a Peacock.
} 
story by Hindu nationalists. The primary object of interest in the video is the Sanjak, which is a peacock lamp commonly used in Hindu temples. For Hindus it is not an object of worship. For Yezidis, however, it is a representation of Tawus Melek, the Peacock Angel, a sacred object which is commonly kissed by Yezidis. For Yezidis in Phoenix, however, this was not the only commonality between the faiths that was generating new kinds of fictive kinships through origin narratives.

Diasporas are communities defined by their relationship to a common homeland or sense of home (Alinia \& Eliassi, 2014; Safran 1991; Cohen 2008). Their common dislocation and relocation outside of the homeland is what shapes their common experience, along with a specific idea of "home" (Alinia \& Eliassi, 2014). For Yezidis, a sense of home has been disrupted by a targeted genocide by ISIS in 2014, which reshaped or enhanced their idea of what made them Yezidi. It was redefined to a common sense of trauma, of loss, and of targeted persecution, even for Yezidis who had already lived abroad outside of Iraq for two decades. Rather than focusing solely on traditional Kurdish or Yezidi "victim" discourses which assemble politically (Alinia \& Eliassi, 2014), most recently through the ISIS attacks, I focus on processes of identity formation and belonging through the project and practice of articulating a common sense of belonging with the Hindu Indian diaspora. Many Yezidi scholars have noted changes in Yezidi culture and identity in the diaspora (Allison, 2013; Kreyenbroek, 2009, 2016; Omarkhali, 2016; Spat, 2005, 2016; Gökçen, 2010, Ackermann, 2004), but few have commented on Yezidi political discourses (Spät, 2018), or diaspora affiliations and lobbying by Yezidis and Christians in the diaspora (PR Newswire, 2015; Morello, 2018; USAID, 2018). Some scholars have speculated about possible historical Yezidi cultural or material connections (Bruinessen, 2018) or origins in India (Gökçen, 2010), however, credible historical evidence is lacking to make the claim. The claim of Yezidi origins in India, nonetheless, have gained meaning for some Yezidis in Arizona and beyond. Under the leadership of the Mir, some Yezidis are exploring a sense of "us" in relation to India. At the same time, members of the Hindu Indian diaspora are also articulating a sense of "us" in relation to Yezidis. Both of these articulations of "us" eclipses Muslim belonging in Mesopotamia and in India, and seeks to distance Yezidi and Hindu histories from shared spatial histories with Muslims.

Members and leaders of the Kurdish speaking Yezidi diaspora in Phoenix, Arizona — and transnationally— are in dialogue with members of the Indian diaspora about their common historical connections. In Phoenix, Arizona, in the transnational space of dialogue in the Yezidis diaspora, and in online forums used by both Yezidis and the Indian diaspora, both groups have raised the question, "Are Yezidis from ancient India, or are Indians from ancient Mesopotamia ${ }^{5}$ ?" Both of these claims and hypotheses situate Yezidis on the temporal and spatial outside of a historical Muslim world, and have material effects. They add validity to non-Muslim traditions, by imagining a historical cultural root structure between India and Mesopotamia. In my research, Kurds were tying their links to India as a way to create a sense of kinship through membership in the same language family (Aryan is a linguistic demarcation within the IndoEuropean language family). This was then used to talk about cultural and biological difference from Muslims.

This ethnographic study is based on two years of regular visits to the homes of six families, their extended family networks, and large community events in 2016 and 2017, and a year and several months of follow up interviews. In Arizona there are around 160 Yezidis as of 2019. Most of the families I have interviewed are based in Phoenix, with a few based elsewhere in Arizona. Each family had approximately 10-15 members of multiple generations. The main languages spoken were Kurdish, Arabic, and English. Initially my oral history and interview questions focused on their migration histories, their roles in preserving Yezidi culture in the diaspora, their experience in the U.S., and their activism for the Yezidi cause.

\section{Imperial Legacies and Yezidi Futures}

Most of the Yezidi families that migrated to the U.S. between 1995-1997 left in order to escape the Saddam Hussein regime. Further, many Yezidi men who migrated to Arizona served as interpreters ${ }^{6}$ during the 2004-2010 U.S. military occupation. Due to their service to the U.S. military they were granted special visas to migrate to the U.S. and apply for green cards. According to interviews, most Yezidis in Arizona moved to the U.S. through these visas and through family reunification. More recently families who escaped ISIS captivity have become the most recent refugees in the Yezidis diaspora. Due to the legacy of U.S. imperial presence in Iraq and the precedence of migration assistance for Kurdish translators to the U.S. Yezidis had a lot of hope that the U.S. government would come to their assistance when ISIS attacked.

\footnotetext{
${ }^{5}$ Mesopotamia is a term for the land between the Tigris and Euphrates river in Northern Iraq. The term is sometimes used synonymously with the land of Kurdistan, the region where Kurdish speakers live which spans Turkey, Iraq, Syrian, Iran and Armenia. Kurdistan has connotations of nationalism, with claims to self-autonomy by Kurds living in these countries, but more commonly in Northern Iraq, Syria and Southern Turkey.

${ }^{6}$ Some Yezidis migrated to Phoenix, Arizona in the late 1990s as refugees from Iraq. Later during the U.S. occupation of Iraq, some community members (men) returned to Iraq to work as interpreters because of the high earnings and salary. This income helped them support their families in the U.S. and start businesses.
} 
In early August of 2014 the attack upon Yezidis at Mt. Sinjar had a major impact on the community, at home and abroad. The "Islamic State of Iraq and Levant" (ISIL/ISIS) or "Daesh" expanded into Yezidi towns and villages at Sinjar (Dulz, 2016). Dulz noted that this event resulted in the displacement of 200,000-300,000 Yezidis from Northern Iraq. ISIS executed all the Yezidi men they captured who were over the age of 14, an estimated 2,000-4,000 men. Many unmarried Yezidi women were abducted into slavery and many were subjected to systematic rape by their owners. Many elderly women and men were killed, and married women with children were also abducted into slavery. Yezidi children were abducted to be trained as ISIS fighters and spies against their own community (Dulz, 2016, pg. 133). As of May 2019, ISIS territories have been largely destroyed and thousands of women and children have taken refuge in refugee camps (Drury, 2019). Other women have traveled to Germany to receive psychological care (Thomas, 2018). Several scholars have noted changes in the practice of the Yezidi faith in Iraq and in the diaspora following the 2014 attacks (Otten, 2018; Spät, 2018). Overall, a greater sense of Yezidi identity has been emphasized in the diaspora, in opposition to other historical affiliations such as Kurdish identity. Seif, a Yezidi activist in Arizona and former U.S. army translator in Iraq, articulated his story of Yezidi recognition and Yezidis' relation to the U.S. government.

Before the 2003 American war, even if you went to Iraq, no one had heard about Yezidis. They say they build a new government and adviser for a new constitution. No one recognized Yezidis and now everyone pronounced the word "Yezidi." At least they know us now. After 2014 after ISIS attacked us, on the 3rd or 4th day Yezidis in America demonstrated in front of the White House saying, "we are not gonna leave until you do something for us." By then the U.S. army had pulled out. ISIS took over $1 / 3$ of the land of Iraq and the U.S. wasn't there because they felt kind of kicked out, and their proposed agreement wasn't recognized by the Iraqi government. Then Obama recognized Yezidis and at the same time the Iraqi Parliamentarian leader cried to get support for Yezidis (this was broadcast globally by the media). Obama said he would help Yezidis. Since then the U.S. army went to the mountains of Sinjar (where the Yezidi people sought refuge) and sent food and water, and the coalition forces fought against ISIS. From 2014 until now the U.S. army worked to defeat ISIS. Today ISIS has no land but many fighters.

\section{Historical Terms of Belonging}

Assertions of difference from Muslims runs counter to historical common cultural traditions with Muslims. Yezidi orthopraxy has been shaped by their cultural environment. Living amongst Muslims, Christians and Zoroastrians and other religious and cultural groups for centuries in Mesopotamia has formed common practices with those groups as well, just as there are many differences.

For example, there is documented evidence of the practice of choosing a Keriv (or Kerif), a kind of God parent who conducts the circumcision ceremony for Yezidi boys. Between families that have a Keriv relationship, families cannot marry into each other's families for seven generations. Historically the Keriv has been chosen from amongst Muslim Kurdish families, to help the Yezidi child navigate society and power dynamics within a dominant Muslim society. "Much like a godfather in Christian culture, a kerif, on whose knees a boy is circumcised, enters a close relationship with the boy and his family. Yezidis often opted for choosing a Muslim kerif in order to procure protection among members of the dominant majority should the need arise. This relationship is considered so close that members of the two families cannot intermarry as that would be considered incestuous (Spät, 2018). Although Yezidis no longer choose Muslim Kerivs and this practice is being forgotten in the diaspora, it gives evidence of historical strategic fictive kinships within Kurdish areas of Iraq.

When I asked Seif, a Yezidi activist in Arizona about the practice of Keriv, he shared the following:

The Yezidi tribes lived among Muslims. If there was a war between Muslim tribes sometimes Yezidis made a coalition with a Muslim tribe or against the Ottoman empire. Keriv was a relationship where they did a circumcision of the boys on the Keriv's lap, of the other family's boy. It was a blood relationship between the families, like a brother in blood. They have some role and agreement to help, support and fight for the each other like a brother. Between Sheikh families of Yezidis and Muslims 
(same social status) and between a Yezidi and Arab tribe. After 2014 it was only between Yezidis.

Historical kinships and coalitions have shifted in the diaspora after the 2014 attack on Sinjar. At times of the justification for these changes has been articulated by Yezidis through Muslim violence, and at other times through racial difference from Muslims in the diaspora.

\section{Ethnic and Racial Claims Amongst Yezidis}

"When I came to this country in 2012 I thought I was white" Seif, a Yezidi Kurdish man told me one morning over breakfast. His wife Seve echoed the same comment, "at work everyone asked me if I was European or Russian." For Seif and Seve, they were often racialized as European in the U.S. For Seif and Seve this was also testament to the fact that they didn't look Arab, or "Muslim," racially. Yezidi meant white (non-Arab), and Muslim meant Arab. "Some people in my family talk about taking DNA tests" to find out whether we are Yezidi or Muslim. I would like to be able to prove that I am Yezidi with this test." Seif was referring not only to the ways in which the test could prove geographic origin of DNA, but to the origin being "Caucasian" or "Arab." If one was Arab, they were Muslim, according to his logic. Seif believed that all Kurds had originally been Yezidi "before Islam came to convert the Yezidis." Seif clarified that the idea that Yezidis had a unique race from Muslim Arabs originated in the Yezidi caste system, in which Yezidis can only marry other Yezidis from the same family caste (Sheikh, Murid, or Pir). For Yezidis, marrying within the religion and the caste system is one of the most important forms of belonging. Proving that none of his relatives had procreative relationships with Arabs for centuries was very important to him. Curiously, what he did not elaborate on was his experience of difference from other "white Europeans" in America. Instead, he focused his response on the authenticity claims of his own Yezidi identity, which was the foremost form of belonging which he pursued. In the diaspora and through new forms of Yezidi nationalism, belonging became defined through racial terms. According to my interviews, some Yezidis began to shape their idea of a Yezidi "race" beyond their own caste system — through Hindu nationalist terms of "Aryan" origins as well.

Notions of race travel and are shaped in the diaspora by local hierarchies. Neda Maghbouleh's important work with the Iranian diaspora in the U.S. gives testament to complex racial categories for people of Middle Eastern descent (Maghbouleh, 2017). Discrimination against people of Middle Eastern descent in the U.S. is well documented. Iranians, Indians and Kurds who identify as Aryan do not fit into definitions of whiteness amongst the U.S, public, as demonstrated by everyday experiences in airports and interactions with border security and the public. This is most clear within right-wing groups who espouse white superiority and narrow racial definitions of what counts as "American." Nonetheless, racial terms have been used by Yezidis and Hindus alike to concretize authenticity and origin claims to claim difference from others.

Hindus in the diaspora were also pursuing authenticity claims based on the cultural norms of the homeland. Thomas describes how the Aryan claims in the right-wing Hindutva movement in India sought to prove that Hinduism is originally from India, including south India (Thomas, 2018). The purpose of this claim is to prove that counter to the Aryan migration claim, Hindus in both north and south India were always in India and not from somewhere else. The story of Aryan migration, supported by archeological evidence, is the claim that Aryans brought horses from central Asia to the Indus Valley after the decline of the Indus civilization (Thomas, 2018). Such claims were racialized by imperialist colonial era scholars who wanted to differentiate north Indians from south Indians by skin scholar, which was equated with different linguistic origins. One of the findings of colonial linguists was that Aryans (north Indians) spoke Indo-European languages, which have commonalities amongst Sanskrit, Greek, Latin, and Persian.

This claim is used to prove that Muslims and Christians are outsiders became they came from somewhere else. The exception to this narrative seems to be the Yezidi mythic origin story. This is one reason why the Mir often states, "I believe the Yezidi came from India" when he is in the company of the HSS. This idea cohered with historical ideas of the Hindutva movement which believed that the Hindu religion used to take up space from India to Mesopotamia, and that the lands of the Kurds were considered Hindu as well. It was not an outsider discourse, but an insider one, meant to mark ancient origins of Hindus themselves as part of a pan-Yezidi and even pan-Zoroastrian imaginary frame (Schmidinger, 2019). It claimed to give evidence of Hindus far reach in other ancient forms outside

\footnotetext{
${ }^{7}$ DNA tests have been used by other minority communities such as Syrian Christians in Kerala to affirm a relationship between race and beliefs. According to Syrian Christians leading this project, "this is an attempt to bring together the results of Syrian Christians in Kerala, India, to evaluate the results and check whether oral traditions and beliefs are in line with genealogical data" (Thomas, 2008, pg. 81).

${ }^{8}$ Seif elaborated, "If I take a DNA test, I don't trust the DNA test for now. If we go to Italy or Greece, they are like us. We are close to Caucuses. In general Yezidis are not white or dark. Americans don't know what people in other countries look like. So even if they guess, they gue ss wrong. “Are they Europeans (about Yezidis)?" I was walking with my son Saeed who is blond with light color eyes, so even Iraqis can't guess I'm Iraqi. They think I'm European. No one in the U.S. ever guesses that I'm from Iraq. I'm not proud to be Iraqi, it is our homeland but it is famous as a Muslim Arab country and I'm not proud to be from that country. The Arab Muslims took over our country."
} 
of the boundaries of north and south India. This idea expands the Hindutva claim of the borders of "Hindu" while excluding Muslims and Christians from the mythic origin narrative, both in India and in Mesopotamia. The Yezidi claim of origins in India, as well as the origin story of Kurds as Yezidi, do something similar. They imagine a common religious and ethnic origin of all Kurdish people, whether they be Muslim or Christian.

\section{Yezidi Identity and Belonging}

An affinity with Hinduism in the form of food practices was explored by the Mir, or prince of Yezidis in Phoenix, Arizona. After visiting the Mir in Phoenix for several months, he told me one day that he was becoming vegetarian, and he hoped to convince his community to follow suit. The Mir explained,

The Ezidi and the Hindu have a lot of similarities. A few things are different. The way they practice the religion is the same as the Ezidi. The only thing is, I don't know what they say. When they do something I see that it's good. The difference is that when they pray I don't know what they say. The best thing I like about them is that they don't eat meat, that I like. I tell my wife, I don't want to eat meat anymore. Every Saturday we have a gathering at the park with Ezidi families. There's a guy who make the food. I tell him, I don't need to eat meat. He says, “oh please please." You see I don't eat anymore. I need to stop them to eat the meat, that's the problem. I don't know how I can do it. For two or three months I tell my wife, I need to stop the meat. She says, ok, eat it this time. Just today. I say OK."

The Mir wanted to shift the terms of belonging to vegetarianism in order to facilitate his relationship with members of the local Indian diaspora community who define meat eating as a Muslim cultural practice. He was exploring new forms of belonging through an affinity with Hindus, while also expressing what Yezidis have in common, which is their feeling of difference from Muslims. He didn't seek to enhance kinship relationships with the Indian diaspora community, but specifically the Hindu community through the Hindutva movement organizations HSS and Seva International. Vegetarianism distinguished the Hindus from Muslims in the context of India. For the Mir, he hoped that it would also differentiate him as an Iraqi Yezidi from Middle Eastern Muslims in the diaspora. This created an important distance for the Yezidi Kurds I got to know in my research. The Mir's wife, however, rejected vegetarianism. In my interviews with her, she argued, "We are Yezidi, not Hindu. We are not going to be vegetarian. Yezidis eat meat!" The Mir continued his efforts, passing up meat at each meal. His wife protested. Many months later, the negotiations in the household over eating meat were ongoing in much the same manner. What is important to note, however, is that the Mir wanted to shift the forms of belonging based on difference from Islam in new cultural forms. It is also part of the ways in which the interactions between West Asia and South Asia are contained through interactions between Yezidis and Hindus. These are both confining and essentialized representations. Vegetarianism was one way of accomplishing that. Why did he want to establish new differences from Islam? The answer is multidimensional. Although Yezidis in Arizona have pursued various kinds of relationships amongst other Diaspora groups (most notably amongst Iraqi Christians), paradigms of difference from Muslims are central to terms of belonging for Yezidis in the diaspora. One issue is the history they came with them from Kurdish Iraq where they have increasingly stressed ethnic difference from Arabs and Muslims, especially after the ISIS onslaught of Yezidis in 2014. The second is the ways in which this community has engaged with the U.S. system of racial classification that positions them in precarious spaces after the 9/11 attacks and the global war on terror (James, 2019; Maghbouleh, 2017; Thangaraj, 2015, Alsultany, 2012). In the case of the Mir in Phoenix, he observed that Yezidis carried a lot of common cultural forms to Muslims, especially in the eyes of the Indian diaspora, with whom the Mir was becoming closely connected. This led him to adopt vegetarianism and enhance his sense of belonging with his allies in the Hindu diaspora.

During the course of research I worked most closely with the Mir and his family, and my reflections and analysis are largely guided by his own experiences, and do not represent the entire Yezidi community of Phoenix or of Arizona9. However, many of his ideas and opinions are shared with other Yezidi leaders and community in the U.S.,

\footnotetext{
${ }^{9}$ Arizona is a unique site of Ezidi migration in part because in spring of 2016 the Arizona community nominated their own Mir, or Prince, as a national leader of Yezidi in the U.S. The Mir's role is important in officiating Ezidi events in the community such as Sere Sal or New Years, and in representing the community at public events. He is also president of the North American Ezidi Federation, an initiative he hopes will represent Ezidis on a national scale. Lincoln, Nebraska, in comparison, hosts an estimated 1,000 Yezidis, and an established NGO called Yazda. Phoenix, Arizona is the only community I know of outside of Germany and Iraq which has a locally nominated Mir.
} 
and transnationally within the Yezidis diaspora in Germany, Sweden, and Canada, Australia and elsewhere. Whenever possible I also consulted Yezidi families in Germany whom I met during preliminary research. I also conducted research with the organization in Phoenix which was affiliated with the Indian right-wing diaspora group Hindu Swayamsevak Sangh, or HSS (known in India as the RSS) with whom the Mir worked closely.

In an interview with Seve, age 55, she told me, "If Muslims become gold, make hole in your pocket." She explained that this meant that however much you trust a Muslim, that much is how they badly they can cheat you. "We couldn't believe how bad Muslims were until we saw what happened to us in 2014." I asked her if she had grown up around Muslims as a young woman. She explained that until 1990 Muslims lived amongst Yezidis. "We planted our crops together with Muslims and we had that agricultural relationship." During Seve's escape to Mt. Sinjar she noted that some of attackers included her Kurdish Muslim neighbors. Her children noted that their school teachers were also taking part in looting and attacking. The event was extremely traumatizing for the family.

In the diaspora, historical narratives of interactions between Yezidis and other groups were reconfigured around Persian- Caucasian origins, despite the existence of well-known common cultural practices amongst Yezidis, Muslims and others in Iraq. For Seif, an identification with the Persian empire concretized his feeling of similarity with the Hindu diaspora.

I believe that area (Mesopotamia), the area of the Persian empire, is very close to Indian culture. This is because the Persian empire took over. It was easy to move for trade, that's why we have something similar. The contact is evident in our common languages. The north of the Indian (Afghanistan, Pakistan, Central Asia, Azerbaijan, Armenia, Georgia), we have a lot in common as tradition, language, as a race, yes, we are similar. Right now in Kurdistan we have no similarity to Arabs, not tradition religion or food, nothing similar. The border between those countries is not open. I don't know how, but the food is the same. The clothes are the same. The singing and music is very close.

Counter to this story of similarity between areas that formerly made up a Persian empire, Arabs were equated with Muslims. Arab Muslims were considered culturally foreign to Seif' notion of 'people of the caucuses and former Persian empire' which included Yezidis.

Islam is something new. The radical Muslim is very new, after 1990. Before that we had Arabs that had no mosques. Now Muslims have so many mosques and wear hijab. In Mosul less than 5\% were wearing hijab after 2004.

For Seif, Islam was something new in the areas of the people of the Caucasus, who were loosely "racially" related. Islam wasn't a "problem" in their immediate lives until Yezidis began to feel othered. They didn't attend mosques or wear hijab in the way that Muslims did. Eventually that status of being an othered minority within an Arab Muslim society served as part the basis of targeted violence against them when ISIS took power.

Research with individual members of the Arizona Yezidi community showed that Yezidi identity was performed through a counter-identification with Islam, which served as one way to deal with collective trauma. Statements such as "If I ever smelled Islam on my finger I would cut it off" were not unusual. There was a strong tendency to sever anything related to Islam and Muslims. This is understandable due to the community's traumatic experiences of targeted killings in 2014 in Sinjar by ISIS. Hindus in India, however, are the majority, and Muslims are a minority religious groups. Their situations are quite different. Nonetheless, the domestic political debates in India and the war between India and Pakistan motivated the nationalist ideas of the HSS and similarly negative ideas about Muslims. While I do not focus on the domestic political issues of the HSS and of right-wing Indian nationalists, the study is informed by the political contexts from which both communities have originated, and the wars which have shaped their political attitudes. As demonstrated above, interactions between the two communities have material, emotional and cultural effects. Discussions of similarities between Yezidis and Hindus have ignited new discussions about their common religious origins. For some Yezidis such as the Mir, a common origin story expands an imaginary of a cultural and religious landscape shared between Yezidis and Hindus, which eclipses historical cultural influences and proximity with Muslims.

\section{Campaign to Send Yezidis to India}

After the events of early 2014, Sri Sri Ravi Shankar, an Indian spiritual guru, initiated a humanitarian mission to Iraq ("Art of Living," 2014). According to Seif, he was one of the first people to initiate help for Yezidis. "He 
collected a million dollars and took it to Iraq. I know they gave scholarships to Yezidi students who wanted to study in India." He was also the first to invite the Baba Sheikh, the religious leader of the Yezidis, to India. Sri Sri encouraged the Indian government to give scholarships for Yezidis to study in India and resettle, as well as accept Yezidi refugees. Sri Sri considered Yezidis to be a minority like the Parsis who needed to be protected (Shankar, 2018). However, Yezidis did not settle in India. "I know many students who went to India to study, but they returned back. They did not want to relocate to India because they wanted to go to Europe" Seif told me. The Hindustan times (Narayan, 2014), admired the humanitarian mission. "As anyone who is plugged in to Indian social networks knows, there is much sympathy for the Yezidi community in the country especially from the Hindu right wing that sees, in its tragic fate, a mirroring of the wrongs perpetrated on Hindus in India by Islamic rule."

In recent years several Yezidi leaders made trips to India to enhance their relationship with Hindus and seek support for displaced Yezidis. Mirza Ismail ${ }^{10}$, an activist from Canada, had visited India in 2015 and in 2017. In a published article he called for India to represent Yezidis at the United Nations (Tare, 2018). Throughout the article Mirza took an anti-Muslim approach in order to attract the assistance of the Indian government, a strategy which he hoped would prove fruitful with the Hindutva allied government. In the article Mirza states,

The Yazidis are facing genocide from the Muslims. They kidnapped our women and children and killed our men. They destroyed our culture and identity when we opposed the conversion. The ISIS attacked us, collected our weapons. They are forcing their cultural identity on us. The ISIS has killed 7,450 Yazidi men and women. The ISIS does not kill Christians because they have support from the western countries. They kill anyone who refuses to convert.

He went onto describe how the Yezidis had been "backstabbed" by the Kurdish forces, and how the U.S. had refused to give Yezidis weapons to defend themselves. He said he wasn't satisfied by the response of the international community. "The US, UK and other European countries did nothing. They support the Kurdish politically, logistically and internationally. The UN is at the mercy of the Muslim countries because they fund it from their oil money." Mirza was referring to alliances with Saudi Arabia by Western countries. Finally the interviewer asked Mirza, "Do you think India would stay aloof because it fears to be called as anti-Muslim if she becomes your voice?" he replied, "India had swung into action in 1971 in Bangladesh because whatever happened there was anti-Hindu. India has intervened at that time." By emphasizing India's record of action in times when Hindus were threatened in war by a Muslim country, he hoped to gain the support of the Indian UN representative. He did not consider the potential repercussions of his anti-Muslim sentiment and the problems of using such sentiment by an Indian UN representative representing Yezidis. Due to his involvement with the Hindutva movement (through HSS and Sewa International and other Indian rightwing groups) he did not doubt that his framing of events as "Muslim" violence rather than "ISIS" violence would create the kinds of alliances Yezidis needed on an international stage.

\section{Sedona, Arizona: New Age Knowledge Production}

One of the most unanticipated aspects of the common origin narrative is the co-production of the narrative by a Sedona, Arizona-based, white American new-age literature writer named Mark Amaru Pinkham who hosts multiple websites, such as Yezidi Truth, Yezidi Sanatan Dharma Society (Fracek, 2015), the Yezidipost (YP, 2017), and others. Pinkham leads tours abroad focused on worship of selected ancient deities through his own new age philosophy, such as the ancient gods and goddesses in Egypt (Pinkham, 2019), and the worship of the Yezidis peacock angel, Tawus Melek. In an interview Pinkham claimed to be the first to have introduced Arizona Yezidis to the Indian diaspora. He has been actively researching historical and mythico origins of the Yezidis for fifteen years. He continues to host some of the most visited newspapers online which propagate the common origin narrative. On Yeziditruth.org he claims that Yezidis migrated to India in 4,000 BCE after a large flood. The evidence for a common origin are mostly material objects, most of which are addressed in this article. They include the Sanjak brass peacock statue, the common images of the peacock, common images of the snake, the visit of the Baba Sheik to the Murugan temple, and the Lalish painting.

In an interview with Pinkham, he informed me that his main goal with the Yezidi community was to convince them of the commonality of their faith with Hinduism, and especially with regard to Tawus Melek being a form of

\footnotetext{
${ }^{10}$ His website is written through an anti-Muslim lens and argues for Yezidi human rights.
} 
"Lord Shiva." He claims to be able to channel visions of ancient cities and deities ${ }^{11}$, and uses this aesthetic visual lens to engage with indigenous communities such as Yezidis. Arizona Yezidis interviewed on Pinkham did not agree with Pinkham's interpretation of the religion, although they welcomed his assistance to fundraise for support. In 2016 Mark and the Mir planned to build a Hindu-Yezidi temple and cemetery in Phoenix to bring together the Yezidis and Hindus in spiritual solidarity, under what Pinkham described as common gods. The particularities of the writer's mystical newage theories and their own engagement with mythic history narratives would be tangential if it were not for the mass circulation of his claims online amongst Hindu nationalists, and the broad participation of his Facebook groups, one of which has 100,000 members as of May 2019. He didn't actively seek to create online forums for Hindu fundamentalists, but through his familiarity with the Hindu diaspora of Phoenix and their HSS organizations, he became known to them. Most of the Facebook groups began as spaces for dialogue between Yezidis and Hindus, but have been largely taken over by anti-Muslim propaganda from right-wing Indian commentators. Pinkham expressed regret at not being able to prevent anti-Muslim propaganda in online groups.

Pinkham's mystical interpretation of the Yezidi faith as one of the ancient faiths which shared an interdimensional presence in the desert of Sedona became a competing narrative of authenticity whereby Pinkham embodied a marketplace driven ${ }^{12}$ version of difference that did not match that of the Yezidis in Arizona. The production of new-age knowledge by Pinkham and its contribution to the common origin Mesopotamia-India narrative is questionable, although politically it is perhaps the most enigmatic form of writing about Yezidis and Hindus which had been produced outside of academic scholarship. How it circulates and to whom it becomes useful, however, becomes more problematic. According to Pinkham it was not written with the intent to justify violent language towards Muslims, but rather to articulate common points between the two faiths through symbols. Symbols became key sites for negotiating not only kinship but also affinity and relations to various others.

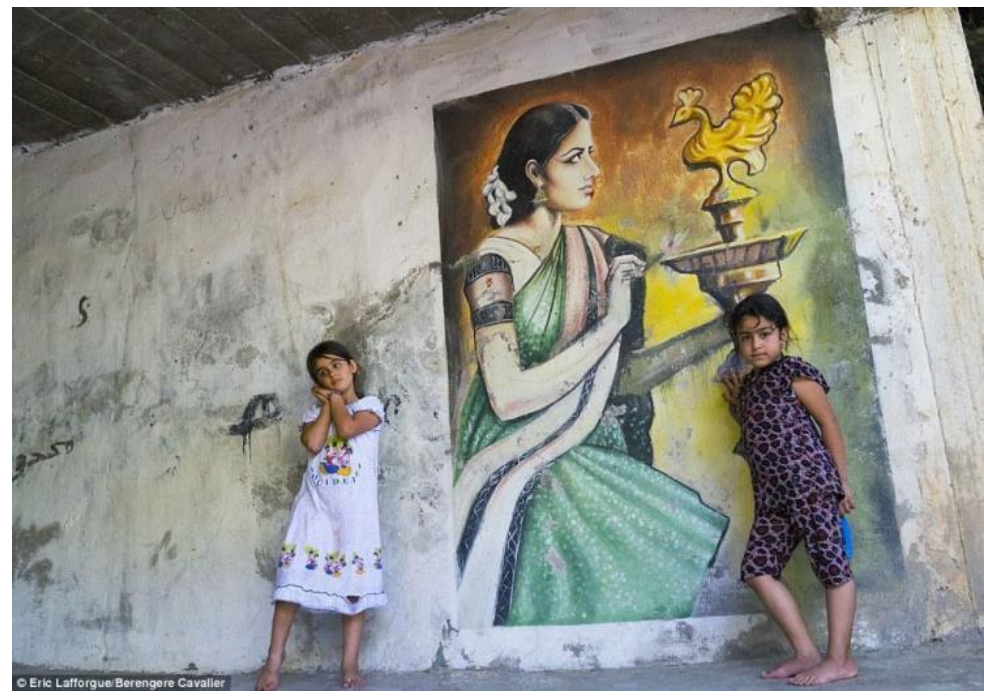

Figure 1. An Indian Painting in Lalish

On a wall at Lalish ${ }^{13}$ in Northern Iraq, the most sacred temple of Yezidis worldwide, is the picture of a woman in a green saree lighting a peacock lamp as shown in Figure 1 (Holland, 2017; Clancy, 2017). It appears on the bottom floor of a building. Yezidis in Arizona say that it was painted by a local Lalish Yezidi painter. This image has been published dozens of times in Indian newspapers, Hindu-nationalist blogs, Yezidi blogs, and in numerous forums. It is often used by Hindu-nationalists as proof that Yezidis are Hindu, have Hindu origins, and should be claimed as part of common Hindu, and possibly Aryan origins. It has been used on Pinkham's website and re-printed dozens of times by Indian Hindu-nationalists as proof of common origins between Yezidis and Hindus. Debates around the painting have revealed the expansive transnational entanglements of nationalisms at work in producing multiple narratives of

\footnotetext{
${ }^{11}$ In his 2015 self-published book "Sedona: City of Star People" he describes how the city of Sedona, Arizona exists on ancient Hopi land (Dunning, 2015). The description reads, "Since 1987, author Mark Amaru Pinkham has been blessed with the ability to envision Palatkwapi as it exists now as an interdimensional city that co-exists with the physical town of Sedona.... The book culminates in Mark's discovery of a royal court composed of red rock temples that he now identifies as the ancient seat of the Hopis King of the World, the Star Being known as Masausu. Through his direct study with the Yezidi priests of Iraq, Mark has further discovered that Masausu is another name for the Yezidis' King of the World, Tawsi Melek, the Peacock Angel, and that the planetary monarch is due to soon make his presence known among the masses."

${ }^{12}$ I interpret his ambitions are partly market place driven because his central business is "sacred tours." If Yezidis validated his claims of an interdimensional court of the Peacock Angel in Sedona, he could stand to profit from tours.

${ }^{13}$ Interestingly, neither the British Independent nor the Kurdish news site mention the "Indian" painting in their photo essays of Lalish.
} 
Hindu-Yezidi mythico origin histories and ethnic-nationalisms. Although it isn't clear who the artist of the work is, or how it became painted on the wall of a building in Lalish, it has transnational affects, linking Yezidis to Indian symbols and cultural artefacts. The peacock image travels along roads in cyberspace from Mesopotamia to India on a circular path. It returns from India reframed through authenticity claims from the Hindutva movement. Whose peacock is it? The lady in the image is a second thought, which anchors the peacock lamp symbol to India through her sari. She is not Yezidi, but her peacock might be.

Other initiatives and cultural products include: Hindu-nationalist humanitarian campaigns to support Yezidis through Sewa International (an RSS organization), multiple Facebook groups devoted to Yezidi and Hindu right-wing Islamophobia with over 10k follows in each, a Yezidi-Hindu Post online newspaper, Pinkham's Sedona, Arizona based Yezidi Sanatan Dharma Society, and possible future collaboration with the HSS. The topic of Yezidi and Hindu nationalisms, and their cultural products grows by the day in material affects, online debates, and affective forms of belonging through common origin theories. This proves critical in producing who the insiders of the community are and who embodies modernity. It creates a sense of family that erases the presence of Muslims and non-Kurds between the land masses of Kurdistan and India. It also refutes other types of cross pollination with Arabs and Muslims.

\section{Imagining Vedic Civilization in Mesopotamia}

In a documentary film written, produced and filmed by Indian film Aditya J. Patwardhan (2017), he interviewed Yezidi elders in Phoenix, Arizona about these narratives of common origins with Indian Hindus. His own historiography revealed a Hindu nationalist angle, imagining that Vedic civilization spread to the Kurdish areas of Mesopotamia. This in many ways challenges the story that folks like Bhagat Singh Thind used in 1923 to argue for Caucasian identity based on the movement of Persians to northern India (Magbouleh, 2017). In a published interview in the Yezidi Post with the filmmaker, he reflected:

Once a prominent sophisticated culture in the times of the Mittani empire, the Yezidis in the modern Islamic times is a culture on way to its extinction. As they migrate further out of their homeland, they lose the connection to their original philosophy, which has already undergone fatal modifications due to the surrounding influence. I believe, and the Yezidi elders agree with this, that the answers to the questions about the Yezidis lie with the Vedic civilization and for this, they look towards it with hope... The Vedic way of life lost itself to dogma in Europe, Middle-east, Afghanistan and Central Asia. The Yezidi is a fading living footprint that it has in the middle east and needs to be saved. Primarily as a people and then also as a living culture. A research facility for the Yezidis, a temple for Melek Taus or even a place for their priests at Hindu temples would only add to the wide galaxy of the vibrant Vedic civilization."

This statement creates its own artifacts, narratives of movement, and manufactured kinship between Yezidis and Hindus which collapses religions, ethnicities, and regions. The solution, according to Patwardhan, lies in Vedic civilization. Rather than recognizing how Yezidi people have shared a common context and even shared traditions with Muslims for centuries, he frames them as lost remnants of a Vedic empire which can be saved by modern Hindus. The "fatal modifications" of the "surrounding influence" perhaps refers to the forced conversations of Yezidis by Muslims. Although forced conversations likely occurred, Yezidi elders have invested in their own religious and cultural histories, rather than relying on Vedic ones. Furthermore, Yezidis have acknowledged mutually beneficial relationships with Muslims in recent history, prior to the 2014 attacks. Although many Yezidi activists use a monolithic notion of "Islam" as violent, they do not often refer to specifically Vedic religious influences, but general common "symbols" and common racial origins which they refer to as "Persian." Many Yezidi activists in the diaspora invest heavily in preserving their own Yezidi cultural traditions, rather than investing in "Hindu" ones, like the Mir has.

Yezidis are quite aware that their experiences are tied to their own homeland context in Mesopotamia, and even to their own nationalism. They are also conscious of the fact that the RSS community is actively trying to organize Yezidis under their own organizational umbrella, the HSS in Phoenix, as my interviews with the RSS attest. Further, Yezidis are alert to the possibility that the Hindu-nationalist organization aims to convert them. The Hindutva movement in India is one which aims to convert more people to Hinduism or erase them, both corporally and symbolically.

\section{Debating Yezidi Identity}


It was exactly this kind of encounter which I witnessed repeatedly between the RSS and the Yezidi diaspora in Arizona. Eventually, the erasure became apparent to others in the community. The wife of the Mir said one day after her husband and I attended a meeting with the local HSS leaders, "I don't know if Yezidis came from India, or if the Hindu came from Kurdistan. We have common symbols like the Peacock. I do know that they want to make the Yezidi Hindu. I am Yezidi, not Hindu." Yezidis in Phoenix were eager to preserve their cultural heritage as Yezidis, especially linguistically. Because the community was small, many of the young children were forgetting Kurdish though the English education system and chose to use English at home instead of Kurdish, much to their grandparent's dismay. The Phoenix community was a kind of sister community to the much larger Yezidi diaspora located in Nebraska. This is perhaps one reason why the Mir sought advocates and alliances amongst other diaspora groups.

Phoenix, Arizona is the second largest Yezidi resettlement city in the U.S. after Lincoln, Nebraska which has around 1,000 Yezidis (Smith, 2015), but it also poses challenges to Yezidis who wish to find marriage partners. Many of the families whom I interviewed had family members who found husbands and wives in Canada, Germany, and Iraq, with few marrying Yezidis locally. Only those who were U.S. citizens had the ability to bring their partners to the U.S. This was something particularly stressful in the community. This is because Yezidis can only marry within a narrow caste system of Murids, Pirs, and Sheikhs. The Sheikh family is particularly restricted with additional castes within the group. Therefore, the U.S. posed a unique challenge in terms of geography and low numbers of asylum and migration. One of the reforms the Mir wants to make for the Yezidis in his community is to change the caste system so the young people can more easily choose marriage partners. In terms of comparing the Yezidi caste system with the Hindu one, Yezidis symbolically understood their caste system to be specific to their religion, as part of the 12th century religious reform by Sheikh Adi. They did not conflate their caste system with a Hindu one. It was considered something very Yezidi.

Of course, compared to the critical vulnerabilities of Yezidi girls being held captive by ISIS in Iraq, and the ethnic genocide of Yezidi men, these issues of identity are less urgent. Based on interviews with Yezidi families, however, the forms of belonging which are central to identity such as marriage practices, language use, and ability to enjoy a social world free of Muslims, were considered very important. A majority of Yezidis in Arizona felt that their own sense of identity was threatened by their new circumstances. When I asked what it meant to be Yezidi, the foremost answer had to do with being different from Muslims. It was apparent that a lot of Yezidis weren't well informed about the nuances of Yezidi religious practice, and identified with the Yezidi identity as an ethnicity. The foremost identity issue which was discussed in the field was their difference from Muslims. With the ways by which Muslim and Arab have become hegemonic identifiers in West Asia/Middle East, there is a need to interject difference and deconstruct these terms at the moment of articulating Yezidi identity.

\section{"War on Terror" and Other U.S. Political Narratives}

Recently Yezidi activists are finding new forums in which to share their narratives of trauma, persecution, and victimhood. I believe it is very important to examine the contexts in which Yezidis are finding a voice, especially in a powerful country such as the United States. In order to facilitate increased mobility for Yezidi refugees to the U.S., Yezidi activists will need strong bipartisan allies under a Trump Administration. It is also important for stakeholders, academics, and policy makers to consider the political contexts in which advocacy for vulnerable groups such as Yezidis is occurring. This is especially crucial since Donald Trump has taken office, and has promoted anti-immigrant and anti-Muslim policies (Thangaraj, 2017).

In 2016 the Mir informed me that Yezidi leaders met with Senator John McCain's office to warn him about "Muslims" and to encourage the Republican party to ban Syrian refugees and other Muslim migrants. Indeed, they problematically conflate all Muslims as potential radical Muslims who could attack like ISIS. This in in spite of the fact that radical Sunni Muslims began to destabilize the region through U.S. occupation. They have launched broad campaigns to alert the world to the Muslim conspiracy of terror and violence, and impending attacks. This kind of language has been embedded within humanitarian claims for support for Yezidi refugees. Yezidi activism and advocacy, and their international voice, finds resonance with the Hindu nationalist diaspora and Rashtriya Swayamsevak Sangh (RSS) political movement in Arizona. Yezidi and Indian diaspora activists claim common negative experiences with Muslims, and with "Islam"-imagined as a monolithic negative force. Rather than being an isolated discourse, my study suggests that Yezidi and Indian diasporas (Thangaraj, 2019) ${ }^{14}$, especially upper-class, upper-caste Hindus, in the U.S. have the potential to produce world-making effects through their common Islamophobic platforms and corresponding ethnic-nationalisms. I read these ethnic-nationalisms as historically rooted in unique national contexts, yet also influenced by the diasporic U.S. cultural context. The 2014 targeted violence by ISIS which produced collective trauma for Yezidis in Sinjar, Iraq, has been articulated on an international stage (Buffon \& Allison, 2016). My ethnographic study based on oral histories shows that Yezidis continue to define their ethnic

\footnotetext{
${ }^{14}$ In his April 3, 2019 blog article Stanley Thangaraj problematizes Indian American activism for Trump.
} 
identity in opposition to "Muslims," even though Yezidis in the U.S. live largely apart from local Muslim diasporas and have limited interactions with U.S. Muslims. The ways in which Islamophobia stands out as a unifying factor becomes apparent when another group which is highly focused on cultural preservation (such as Hindus) (Shankar, 2014), enters into dialogue with Yezidi community leaders. It becomes clear that Yezidis haven't focused on cultural preservation in the Diaspora, but rather, have focused on the forces which caused the large migration of Yezidis out of Shingal and Sheikhan since 2014, and during the Gulf war. Most of the Yezidis in Arizona left during the Gulf war, yet, have only recently become involved in activism on broad scales outside of their community.

Scholars of the war on terror have emphasized that although historically people of Middle Eastern descent have been legally categorized as "white" they have come to represent the brown bodies of "terrorists" (Gualtieri, 2009; Puar, 2007). These studies assert that Middle Eastern people do not always benefit from "white-skin privilege" (Cable, 2013), even when they espouse ideals of assimilation. The war on terror discourses reframe Middle Eastern people, from invisible to visible subjects. The social and cultural ramifications of $9 / 11$ reveal shifts in what it means to embody radicalized foreignness in a new U.S. cultural climate. As Maghbouleh's work demonstrates, Persian "aryan" authenticity discourses of original "whiteness" do not translate to the U.S. context in practice. The Iranian subjects of her study were scrutinized under the security mechanisms of the state, similar to the ways in which Yezidi refugees are prevented from migrating to the U.S. under Trump's decreased refugee policies.

The war on terror refers to the U.S. government's actions after September 11th, 2001 to prevent terrorism by Muslim extremists. War on terror rhetoric consolidated the cause of threat to the United States as a Muslim one. According to research on American public opinions of Muslims, American Muslims were often considered "violent and untrustworthy"(Sides \& Gross, 2013, pg. 583). Imagining Muslims both at home and abroad as a monolithic negative force has been one of the effects of the war on terror. These kinds of discourses have animated and justified many political policies, not to mention war, towards the Middle East since 2001. Domestically, hate crimes against Muslims has increased to the highest levels since 2001 (Lichtblau, 2016). Since Donald Trump has been elected, Muslims have continued to be targeted for hate crimes. The executive order for a travel ban was intended by Trump to be a "total and complete shutdown of Muslims entering the United States" but later became "extreme vetting" (Bier, 2018). Iraq was originally included in the ban. At the time when Iraqis were banned by Trump, the Mir's wife was pleased with the decision, but disappointed that her son could not get married to his fiancé who was Iraqi and living abroad. Other Yezidis were sure that Trump would soon realize the vulnerable situation for Yezidis, and make a special policy for them to receive visas and migrate to the U.S. At the time of writing the visa restriction has been lifted for Iraqis but there has not been a large increase in mobility for Yezidis entering the United States.

The difference between trauma narratives and anti-Muslim propaganda is a very important distinction, and I believe it is important for Yezidis to share their experiences in order to quicken mobility for refugees. However, it is important for advocates of victims of violence to keep an awareness of when and where those narratives can be used for propaganda to harm local immigrants, and prevent mobility for other refugees, such as Syrians. In India, for example, the idea of a Muslim "killer next door" is a widely discussed threat amongst Hindu nationalists. When I searched for articles comparing Hindus and Yezidis, I found a number of trauma narratives which aimed to use the Yezidi genocide to justify violence against Muslims in India, where Muslims are a minority.

The Mir had been collaborating with the HSS (international RSS wing) in Phoenix for three years. The HSS is the international wing of the RSS (Rashtriya Swayamsevak Sangh), a right-wing militant Hindu nationalist (Hindutva) political movement which began in the 1920s in Gujarat, which became a prominent generator of antiMuslim propaganda in India (Basu, 1993). This is the same Hindu-nationalist movement that produced Narendra Modi, the current President of India, who was banned from the U.S. for a decade due to his involvement in the Gujarat massacre of 2,000 Muslims over three days in 2002 when he was governor. The same group was connected to a Facebook group called Yezidi Hindu Truth, with over 60,000 members. Both online and offline, Yezidi activists and Hindu nationalists found that they had two things in common: support for Trump, and a common belief that Muslims were inherently violent and should be banned from entering the U.S.

Yezidis have been actively campaigning with Republican Party leaders for increased mobility for Yezidis to the U.S. In 2016 the Mir, traveled with a well-connected Republican Party political organizer to Nevada where he met with Republican senators and congressmen, and were scheduled to meet with Vice President Pence. Right-wing political participation by Yezidis who are anti-Muslim do not represent all Yezidis in the U.S., such as Yezidis in Nebraska, or the Texas based organization Yazda. However, it is Arizona Yezidis who are currently working towards becoming closest to the U.S. centers of power through the Republican Party. Yezidi leaders have met with VP Pence in Washington DC to address a large group of senators. Under the Trump Presidency over the past three years, they have focused on gaining the support of the U.S. government for the mobility of Yezidis to the U.S., and for weapons 
to ensure self-protection of Yezidi areas in Iraq, or in an area in the Nineveh plain claimed for autonomous rules by Yezidis called "Ezidxan."

In 2018 Vice President Pence redirected USAID funds in Iraq specifically for Christians and Yezidis (Morello, 2018). The funds are allocated for the rebuilding of Yezidi and Christian areas that were devastated by ISIS attacks. This decision has been criticized for redirecting funds in Iraq meant to help all displaced peoples solely to minorities (Tamkin, 2018). It has the potential to further alienate Christians and Yezidis from the local populations of displaced Muslims, challenging the peaceful re-integration of Iraqi communities in the future.

\section{Conclusion}

Undertaking ethnographic work with the Yezidi diaspora community has unearthed unlikely bedfellows, the Hindu Indian right-wing diaspora and the Yezidi cause as represented by Yezidi leaders and activists. These communities create a sense of commonness and articulate a goal of self-preservation through anti-Muslim language. This is enhanced by common origin stories which negate the presence of Muslim neighbors in their respective contexts, despite the evidence that both groups have lived mostly peacefully with Muslim neighbors for centuries. The reason for the recent shift is accounted for by recent traumas and conflicts, and also the political context of the present times. It is extremely difficult and unpopular to critique a community which has been the target of a brutal genocide by ISIS. What makes this critique more justifiable is their collaboration with a right-wing group from India which has been linked to brutal atrocities against Muslims. Through this analysis I aim to make an intervention into how we study power. Resistance is not a refusal of power for Yezidis but a different articulation of difference that ostracizes Muslims.

Claiming difference from Muslims in non-Middle Eastern contexts, such as the U.S., has the potential to bring Yezidi activists into powerful political circles with political groups who may ultimately be anti-Muslim, in the case of the HSS, or anti-immigrant and anti-Muslim, in the case of the Republican Party under Trump. This is not only a U.S. phenomenon but is transnational one. Maintaining a proximity to right-wing coalitions in the U.S. is especially problematic as Trump has made his anti-immigrant and white supremacist agenda quite clear. I believe Yezidis will try to gain support from any group who have the power to help them. Any support Yezidis can garner will certainly be useful to the mobility of Yezidis towards protection and spaces where they can maintain their culture and religion.

Common origin stories between Yezidis and Hindus have helped both Hindu nationalists and Yezidis in the diaspora to displace historical Muslim culture in their respective contexts to somewhere else while reinforcing tropes of Islam synonymous with the "war on terror." By de-historicizing Islam and its presence in the Middle East and in India, Hindu and Yezidi community leaders co-imagine a pan-polytheism with roots in ancient Persian (Kurdish) Yezidi culture and language. The contradictions of that historical narrative point to the limits of this historical work in the two communities, and find limits in modern identity articulations of Yezidi identity and Hindu identity alike. Material effects of the historical narrative include Indian imagery on the wall of Lalish, online circulating images and articles equating Yezidis to Hindus, and common activism, fundraising, and humanitarianism between Yezidi and Hindu communities in Phoenix, India, and in the Middle East.

Authenticity narratives of Yezidis (which find a parallel mirror in Hindu authenticity claims) are framed through anti-Muslim language. It is through this language that both seek a sense of belonging. Yezidi activists whom I interviewed failed to self-reflect critically on the politics of their own citizenship under the U.S. as an imperial power. Afterall, it was the U.S. which created the conditions for their displacement (Espiritu, 2014) through the U.S. occupation in Iraq and the resulting mobilization of Wahhabi forces. The U.S. government also severely limits migration to the U.S. by Yezidis who seek refuge from the destruction and violence which resulted. Through their antiMuslim sentiment they have not yet secured their own safety within U.S. borders, and have not yet secured military support for their autonomy claims in Iraq.

Nonetheless, through their activism, Yezidis have the ability to influence the securitization mechanisms of the state, as well as U.S. militarization in the Middle East. Yezidi community members in Phoenix have been part of broad campaigns to alert the world to the Muslim "conspiracy" of terror and violence, and impending attacks, although Muslim refugees have never committed an attack on U.S. soil. For Yezidi futures in the U.S., I see a form of antiMuslim activism eclipsing other forms of belonging, other alliances, and activisms at a very critical moment. This has the potential effect of further aligning Yezidis with right-wing groups who will ultimately not recognize the Yezidi diaspora as "American," as "white enough," despite their political position. This has implications beyond the U.S. context and beyond the present. The right-wing alliances between diaspora groups, such as Yezidis and Indian Hindus, will likely outlast the political administrations of 2019. The broader implications of this study are that when violent conditions of displacement cause trauma and facilitate new alliances in the diaspora, new forms of kinship and cultural practices strengthen the political sentiments which drew them together, which may last for generations to come. More assistance for Yezidis from other nations, and assurance of protection in Iraq, will be necessary to prevent further polarizing effects of the 2014 genocide for Yezidis in the diaspora. 


\section{References}

Abdulhadi, Alsultany, Naber, Abdulhadi, Rabab, Alsultany, Evelyn, \& Naber, Nadine Christine. (2011). Arab \& Arab American feminisms : Gender, violence, \& belonging (1st ed., Gender, culture, and politics in the Middle East). Syracuse, N.Y.: Syracuse University Press.

Ackermann, A. (2004). A double minority: Notes on the emerging Yezidi diaspora. In Diaspora Identity and Religion: New Directions in Theory and Research (pp. 156-169). Routledge Taylor \& Francis Group.

Alinia, M.. \& Eliassi, B. (2014). "Temporal and Generational Impact on Identity, Home(land) and Politics of Belonging Among the Kurdish Diaspora.” Nordic Journal of Migration Research. Special issue article 4:2, 73-81. DOI: https://doi.org/10.2478/njmr-2014-0008

Allison, C. (2013). Unbelievable Slowness of Mind: Yezidi Studies from the Nineteenth to Twenty-First Century. The Journal of Kurdish Studies, VI, 1-Alsultany, E. (2012). Arabs and Muslims in the media: Race and representation after 9/11. NYU Press. DOI: 10.2143/JKS.6.0.2038086

Art of Living reaches out Yazidis, Shias and Christians in Iraq. (2014, October 28). Retrieved June 7, 2019, from https://www.srisriravishankar.org/work/peace-initiatives/art-of-living-reaches-out-yazidis-shias-christiansin-iraq/

Basu, T., Datta, P.Sarkar, S., Sarkar, T. and Sen, S.. (1993). Khaki Shorts, Saffron Flags: A Critique of the Hindu Right. New Delhi: Orient Longman

Bier, D. (2018, December 10). Trump might not have gotten his 'Muslim ban.' But he sure got his 'extreme vetting.' Retrieved June 8, 2019, from https://www.washingtonpost.com/opinions/2018/12/10/trump-might-not-havegotten-his-muslim-ban-he-sure-got-his-extreme-vetting/?noredirect=on\&utm_term=.47a53012cf46

Cable, U. (2013, March) Review: New wave Arab American studies: Ethnic studies and the critical turn. American Quarterly, 65(1), 231-243.

Clancy, L. K. (2017, September 11). PHOTOS: Take a walking tour of Lalish's main temple. Retrieved May 23, 2019, from https://www.kurdistan24.net/en/culture/98cbfcad-8714-4c39-bc2f-ca83c1ed28e5

Cohen, Robin. (2008). Global Diasporas: An Introduction. International Migration Review 32 (3). DOI: $10.2307 / 2547774$

Buffon, V., \& Allison, C. (October, 2016). The gendering of victimhood: Western media and the Sinjar genocide.” Yezidism and Yezidi studies in the early 21st century. Journal of Kurdish Studies, 4(2), 122-130.

Drury, F. (2019, February 21). Islamic State: Thousands of foreign children in Syrian camps. Retrieved June 7, 2019, from https://www.bbc.com/news/world-middle-east-47304399

Dulz, I. (October, 2016.) "The displacement of Yezidis after the rise of ISIS in northern Iraq." Yezidism and Yezidi studies in the early 21st century. Journal of Kurdish Studies, 4(2), 122-130. http://dx.doi.org/10.33182/ks.v4i2.425

Dunning, C. (2015). Mark Amaru Pinkham: Sedona, City of star people. Retrieved June 9, 2019, from https://www.earthancients.com/?portfolio=mark-amaru-pinkham-sedona-city-of-star-people

Editor, A. Y. (2017). Yezidi post. Retrieved June 8, 2019, from https://yezidipost.wordpress.com/

Espiritu, Y. L. (2014). Body counts: The Vietnam War and militarized refugees. University of California Press. http://dx.doi.org/10.1525/9780520959002

Fracek, S. (2015, January 26). Who are the Yezidis? What is their connection to Hinduism? Why has ISIS targeted them? Retrieved June 8, 2019, from

https://www.mythicistmilwaukee.com/mythicistmilwaukeeblog/2015/1/26/who-are-the-yezidis-what-istheir-connection-to-hinduism-why-has-isis-targeted-them

Gökçen, A. Tee, C. (2010) Notes from the Field: Yezidism: A New Voice and an Evolving Culture in Every Setting, British Journal of Middle Eastern Studies, 37:3, 405-427, DOI: 10.1080/13530194.2010.524442

Gualtieri, S. (2009). Between Arab and White: Race and Ethnicity in the Early Syrian American Diaspora. University of California Press.

James, W. Y. (2019). Imprint of Racism: White Adult Males' Transformational Experience from Racial Antipathy to Racial Reconciliation. American Journal of Qualitative Research, 3(1), 93-116. https://doi.org/10.29333/ajqr/5813

Harrigan, P. (2015, September 6). Yezidis and Hindus make common cause under 'Peacock Angel' - Yezidi Baba Sheikh at Washington DC Murugan Temple. Retrieved June 7, 2019, from http://www.worldhindunews.com/2014/12/08/36895/yezidis-and-hindus-make-common-cause-underpeacock-angel-yezidi-baba-sheikh-at-washington-dc-murugan-temple/ 
Harrigan, P. (2014, November 19). Retrieved June 08, 2019, from https://www.youtube.com/ watch?v=AHXLkDVnAuI

Holland, R. (2017, May 12). The holy village Yazidis are coming back to. Retrieved June 8, 2019, from https://www.independent.co.uk/travel/middle-east/lalish-yazidi-kurdistan-sheikh-adi-ibn-musafir-erbilpeacock-angel-sinjar-isis-a $7726486 . h t m l$

Ismail, M. (n.d.). Yezidi Human Rights Organization-International. Retrieved June 7, 2019, from http://www.yezidihumanrights.org/

Kreyenbroek, P. G. (2009) Yezidism in the Diaspora: Different Generations speak about their religion. Wiesbaden.

Kreyenbroek, P. G. Omarkhali, Khanna. (2016, October) Introduction to special issue: Yezidism and Yezidi Studies in the early 21 st century. Journal of Kurdish Studies, 4(2), 122-130. DOI: 10.33182/ks.v4i2.424

Lichtblau, E. (2016, November 15). U.S. Hate Crimes Surge 6\%, Fueled by Attacks on Muslims. Retrieved June 8, 2019, from https://www.nytimes.com/2016/11/15/us/politics/fbi-hate-crimes-muslims.html

Mahmood, S. (2016). Religious Difference in a Secular Age: A Minority Report. Princeton University Press. http://dx.doi.org/10.1515/9781400873531

Maira, S. (2016). The 9/11 Generation: Youth, Rights, and Solidarity in the War on Terror. NYU Press. http://dx.doi.org/10.18574/nyu/9781479817696.001.0001

Maghbouleh, N. (2017). The limits of Whiteness : Iranian Americans and the everyday politics of race. Stanford University Press.

"Middle east christian committee" advocate at the UN for yezidis and christians facing genocide. (2015). PR Newswire Europe Including UK Disclose, Retrieved from http://ezproxy.library.arizona.edu/login?url=https://searchproquest-com.ezproxy2.library.arizona.edu/docview/1728638381 ?accountid=8360

Morello, C. (2018, June 16). Under pressure from Pence, U.S. aid is directed to Christian, Yazidi communities in Iraq. Retrieved from https://www.washingtonpost.com/world/national-security/under-pressure-from-pence-usaid-directed-to-christian-yazidi-communities-in-iraq/2018/06/15/815d8e60-6f4c-11e8-afd5778aca903bbe_story.html?utm_term=.e6eec3d53253. Accessed June 7, 2019.

Naber, N. (2012). Arab America: Gender, Cultural Politics, and Activism. New York: New York University Press.

Narayan, M. (2014, November 30). Yezidis wait for help in fight against IS; Ravi Shankar to the rescue. Retrieved June 7, 2019, from https://www.hindustantimes.com/india/yezidis-wait-for-help-in-fight-against-is-ravishankar-to-the-rescue/story-wZmQhpvoU4I661GvLiAByK.html

Omarkhali, K. (October, 2016). Transformations in the Yezidi tradition after the ISIS attacks: An interview with Dr. Ilhan Kizilhan. Yezidism and Yezidi Studies in the early 21st Century. Journal of Kurdish Studies, 4,(2), 122130. http://dx.doi.org/10.33182/ks.v4i2.429

Otten, C. (2018, January 04). How ISIS changed the Yezidi religion. Retrieved June 7, 2019, from https://www.theatlantic.com/international/archive/2017/12/how-isis-changed-the-yezidi-religion/548651/

Patwardhan, A. (May 3, 2017.) Eastern Shores of the Western World--The Middle East Experience. Yezidi Post. Retrieved March 8, 2019. http://yezidipost.com/2017/05/03/eastern-shores-of-the-western-world-the-middleeast-experience/

Pinkham, M. (2011). Yezidis and Hindus: Re-uniting as one people. Retrieved June 7, 2019, from http://www.yeziditruth.org/yezidis-and-hindus-re-uniting-as-one-people

Pinkham, M. (2019). Sacred Sites Journey. Retrieved June 8, 2019, from http://www.sacredsitesjourneys.com/EgyptNov2019/Egypt-Nov2019.htm

Puar, J. (2007). Terrorist Assemblages: Homonationalism in Queer Times. Duke University Press. http://dx.doi.org/10.1215/9780822390442

Rana, J. (2011). Terrifying Muslims: Race and Labor in the South Asian Diaspora. Durham \& London: Duke University Press. http://dx.doi.org/10.1215/9780822393665

Safran, W. (1991). Diasporas in Modern Societies: Myths of Homeland and Return. Diaspora: Journal of Transnational Studies, 1, (1), 93-99. DOI: 10.1353/dsp.1991.0004

Said, E. (1978). Orientalism. Pantheon Books. http://dx.doi.org/10.4324/9780203092170-13

Sides, J., \& Gross, K. (2013, May). Stereotypes of Muslims and support for the war on terror. The Journal of Politics, 75(3), 583-598 The University of Chicago Press on behalf of the Southern Political Science Association. http://dx.doi.org/10.1017/S0022381613000388

Shankar, R. (2018, March 23). Why we help Iraq's Yazidis. Retrieved June 7, 2019, from https://thehill.com/opinion/national-security/379798-why-we-help-iraqs-yazidis

Shankar, G. S. (2014, November 16). Retrieved June 08, 2019, from https://www.youtube.com/watch?v=ApRku2YGKA\&feature=youtu.be

Smith, M. (2015, September 08). Yazidis Settle in Nebraska, but Roots Run Deep in Iraq. Retrieved June 8, 2019, from https://www.nytimes.com/2015/09/08/us/yazidis-settle-in-nebraska-but-roots-run-deep-in-iraq.html 
Spät, E. (2005). 'Changes in the Oral Tradition of the Yezidis of Iraqi Kurdistan', Journal of Kurdish Studies, 5, pp. $73-83$

Spät, E. (2016, October). Hola hola Tawusi Melek, hola hola Sehidet Singale: Persecution and the developent of Yezidi ritual life. Yezidism and Yezidi Studies in the early 21st Century. Journal of Kurdish Studies, 4(2), 122-130. http://dx.doi.org/10.33182/ks.v4i2.426

Spät, E. (2018, September). Yezidi identity politics and political ambitions in the wake of the ISIS attack." Journal of Balkan and Near Eastern Studies, 20(5), 420-438 DOI: 10.1080/19448953.2018.1406689

Schmidinger, T. (2019). The battle for the mountain of the Kurds : Self - determination and ethnic cleansing in the Afrin Region of Rojava. PM Press.

Tamkin, E. (2018, September 18). Here's What Happened To A USAID Official Who Ran Afoul Of Mike Pence. Retrieved from https:/www.buzzfeednews.com/article/emilytamkin/usaid-christians-aid-iraq-penceinterference. Accessed June 7, 2019.

Tare, K. (2018, February 05). We want India become our voice at the UN, says Yazidi leader. Retrieved June 7, 2019, from https://www.indiatoday.in/india/story/we-want-india-become-our-voice-at-the-un-says-yazidi-leader1162378-2018-02-06

Thomas, S. (2018). Privileged minorities: syrian christianity, gender, and minority rights in postcolonial India. University of Washington Press.

Thangaraj, S. (2015). They Said 'Go Back to Afghanistan': South Asian American basketball culture and challenging the "terrorist" stereotype." Ameriasia Journal, 41(2), 25-46. http://dx.doi.org/10.17953/aj.41.2.25

Thangaraj, S. (2015). Desi Hoop Dreams: Pick-Up Basketball and the Making of Asian American Masculinity. New York: New York University Press. http://dx.doi.org/10.18574/nyu/9780814770351.001.0001

Thangaraj, S. (July, 2015) American public spaces and gender: Muslim America, sport, and activism.” In S. Joseph \& S. Gualtieri, (Eds.), Encyclopedia of Women in Islamic s Cultures. Leiden: Brill.

Thangaraj, S. (October 2014)."'Liting it up': Indo-Pak basketball and finding the American-Ness in South Asian American institutions.” In R. King (Ed.), Asian Americans in Sport and Society. Abingdon: Routledge.

Thangaraj, S. (2019, April 03). Green cards and red lights: The Problem with Indian American activism. Retrieved June 8, 2019, from https://tropicsofmeta.com/2019/04/03/green-cards-and-red-lights-the-problem-withindian-american-activism/

USAID. (July 25, 2018). Episode Six - Assisting Persecuted Communities in Iraq. Retrieved from https://www.usaid.gov/usaid-leads/ep-006-jul-2018.

Van Bruinessen, M. (2018, August 13). Middle East Institute. Retrieved June 7, 2019, from https://mei.nus.edu.sg/think_in/following-the-trail-of-a-peacock-from-northern-iraq-to-singapore-andbeyond-part-3/

Editor, A. Y. (n.d.). Yezidi Post. Retrieved June 8, 2019, from https://yezidipost.wordpress.com/

Yazda Global Yazidi Organization. (n.d.). Retrieved June 8, 2019 from https://www.yazda.org/ 